\title{
KOMUNITAS MEREK: ANTECEDENTS DAN CONSEQUENCES DARI PARTISIPASI KONSUMEN
}

\author{
Made Dwi Utari $^{{ }^{*}}$, I Gede Ketut Warmika ${ }^{1}$ \\ ${ }^{1}$ Fakultas Ekonomi dan Bisnis Universitas Udayana \\ Jalan P.B. Sudirman, Denpasar, Bali 80112, Indonesia \\ * Penulis korespondensi; E-mail: utari.cassie@hotmail.com
}

\begin{abstract}
Abstrak
Pemasaran kini menyusun strategi berdasarkan komunitas konsumen yang terbentuk. Komunitas konsumen yang menjadi perhatian adalah komunitas merek. Kesuksesan komunitas merek ditentukan oleh partisipasi anggota di dalamnya. Tulisan ini mengungkap hal-hal yang mempengaruhi partisipasi konsumen dan perilaku konsumen yang dapat ditimbulkannya. Penelitian dilakukan melalui media internet terhadap komunitas merek virtual Android dalam bentuk forum online dan komunitas merek virtual Android yang terbentuk dalam jejaring sosial Facebook. Hipotesis diujikan dengan total 160 responden dan data penelitian dianalisis dengan SEM (Structural Equation Modeling). Hasil penelitian ini menunjukkan bahwa terdapat pengaruh positif signifikan baik dari identifikasi komunitas maupun kepuasan komunitas terhadap partisipasi konsumen. Adanya pengaruh positif signifikan dari partisipasi konsumen baik terhadap WOM maupun brand image. Partisipasi konsumen berpengaruh negatif signifikan terhadap switching intention.
\end{abstract}

Kata kunci: Komunitas merek virtual, partisipasi konsumen, kepuasan konsumen

\begin{abstract}
Marketers lately built strategies based on consumer communities exist in the market. Community that drew most of marketer's attention was brand community. Brand community's succession was influenced by consumer participation inside it, so that this article revealed variables which influenced consumer participation and consumer's behaviors arose. This research took place through internet on Android virtual brand communities, those were online forums and Android virtual communities developed in Facebook. Data was analyzed with SEM (Structural Equation Modeling). The research found that there were significantly positive influenced whether of community identification or community satisfaction on consumer participation. Significantly positive influenced of consumer participation whether on WOM or brand image. It significantly negative influenced of consumer participation on switching intention.
\end{abstract}

Keywords: Virtual brand community, consumer participation, consumer satisfaction

\section{Pendahuluan}

Dunia pemasaran tidak pernah lepas dari istilah merek (brand). Asosiasi Pemasaran Amerika (Kotler \& Keller 2009, p. 332) mendefinisikan merek sebagai nama, istilah, tanda simbol, atau rancangan, atau kombinasi dari semuanya, yang dimaksudkan untuk mengidentifikasi barang atau jasa yang dijual dan mendiferensiasikannya dari barang atau jasa pesaing. Konsumen mengenali merek melalui pengalaman masa lampau dengan produk, dan program pemasarannya. Ketika keadaan konsumen menjadi rumit, sibuk, atau kekurangan waktu, peran merek untuk menyederhanakan pengambilan keputusan dan pengurangan risiko menjadi sangat kuat (Kotler \& Keller 2009, p. 333). Kesetiaan terhadap merek dapat memberikan kemampuan prediksi dan keamanan jumlah permintaan bagi perusahaan sekaligus menciptakan hambatan bagi perusahaan lain untuk memasuki pasar. Walaupun pesaing dapat dengan mudah meniru rancangan produk, pesaing tidak bisa melampaui kesan produk di benak konsumen. Dalam pengertian ini, merek dapat dilihat sebagai sarana untuk mengamankan keunggulan bersaing yang kuat (Kotler \& Keller 2009, p. 333).

Dunia pemasaran tersebut terlihat adanya perubahan dalam beberapa dasawarsa ini belakangan ini. Saputri (2009) dalam penelitiannya menyebutkan bahwa pemasaran tidak lagi menjalankan strategi pemasaran segmentasi, melainkan mulai beralih membagi pasar ke dalam komunitas-komunitas. Fenomena ini menyebabkan munculnya strategi pemasaran yang berbasis komunitas. Komunitas yang menjadi perhatian pemasar adalah brand community 
(komunitas merek). Penelitian mengenai komunitas merek telah menjadi topik menarik dalam penelitian akademik maupun praktik pemasaran (Carlson, Suter, \& Brown 2008; Woisetschlager, Hartleb, \& Blut 2008; Muniz Jr. \& O’Guinn, 2001). Komunitas merek menurut Muniz Jr. and O'Guinn (2001) adalah komunitas yang terspesialisasi, tanpa batas geografis, yang terbentuk atas beberapa hubungan sosial terstruktur di antara penggemar jasa maupun produk suatu merek. Arah penelitian ini meneliti mengenai hasil dari keikutsertaan konsumen dalam komunitas merek. Selain itu, melihat pada perbedaan yang dirasakan dari perilaku konsumen yang tergabung dalam komunitas merek dengan konsumen yang tidak tergabung dalam komunitas merek. Semakin besar integrasi konsumen dengan komunitas merek, maka semakin tinggi loyalitas konsumen kepada merek tersebut. Pengalaman yang diperoleh konsumen dari komunitas merek memperkuat hubungan konsumen dengan merek, produk, perusahaan pemilik merek, dan konsumen sesama pengguna merek (McAlexander, Schouten \& Koenig 2002; McAlexander, Kim \& Roberts 2003).

Berdasarkan uraian di atas, dapat dilihat bahwa hal yang esensial dalam kesuksesan komunitas merek adalah interaksi antar anggota komunitas. Penelitianpenelitian mengenai komunitas merek sebelumnya sering menggunakan teori-teori psikologi sebagai landasan dalam menganalisis hubungan antar pribadi (Woisetschlager et al., 2008; Heere et al., 2011; Goellner \& Katharina, 2012) dan PSOC (Psychological Sense of Community) pada penelitian Woisetschlager et al. (2008) dan Carlson et al. (2008).

Penelitian ini mengadaptasi suatu fenomena yang saat ini terjadi pada persaingan gadget ke dalam konseptual model yang dikembangkan dalam penelitian Woisetschlager et al. (2008). Fenomena tersebut adalah kejayaan operating system Android di pasar gadget. Hal ini terlihat dari fakta bahwa Android dapat mencapai penjualan $64,2 \%$ smartphone di pasar global (JIBI, 2013), yang mana angka ini mengalahkan platform mobile lainnya. Popularitas Android yang kini merajai $80 \%$ penjualan smartphone di Indonesia (Tentangdunia, 2013) membuat penggunanya semakin terikat dengan merek ini. Penggunaan gadget pada dasarnya sangat bergantung pada operating system yang tertanam di dalamnya. Komunitas virtual (virtual community) itu sendiri didefinisikan oleh Royo-Vela and Casamassima (2011) sebagai integrasi sekelompok individu yang menggunakan internet untuk memelihara hubungan sosial dalam lingkungan dengan minat yang sama. Oleh karena itu, komunitas merek virtual (virtual brand community) didefinisikan sebagai komunitas merek yang dikembangkan secara online (yaitu melalui jaringan internet) dengan karakteristik komunitas virtual.

Penelitian dilakukan pada komunitas-komunitas merek virtual Android, dengan mengembangkan konseptual model pada penelitian Woisetschlager et al. (2008). Variabel-variabel yang dipertahankan adalah variabel identifikasi komunitas dan kepuasan komunitas. Variabel tersebut merupakan variabel penyebab partisipasi konsumen dan variabel Word of Mouth dan Brand Image sebagai konsekuensi partisipasi konsumen, dengan menambahkan variabel Switching Intention (keinginan untuk berpindah) juga sebagai konsekuensi partisipasi konsumen. WOM merupakan komunikasi mengenai produk/jasa yang dilakukan oleh konsumen setelah mereka merasa dipuaskan oleh produk/jasa tersebut. Brand image terbentuk dalam benak konsumen salah satunya setelah merasakan sendiri manfaat yang diberikan produk/jasa melalui penggunaan langsung, dan switching intention timbul setelah konsumen melakukan evaluasi terhadap penggunaan suatu produk/jasa.

Beberapa alasan peneliti menggunakan word of mouth dan brand image sebagai variabel dependen konsekuensi partisipasi konsumen adalah karena variabel-variabel ini merupakan hasil dari keikutsertaan konsumen pada komunitas merek (Woisetschlager et al., 2008; Royo-Vela \& Casamassima, 2011), dan merupakan keluaran yang penting dalam menyukseskan komunitas merek. Dalam penelitiannya, Goellner and Katharina (2012) menyatakan bahwa WOM merupakan keluaran yang paling diinginkan oleh perusahaan yang mengembangkan komunitas merek bersanding dengan loyalitas merek dan ekuitas merek. WOM memiliki pengaruh kuat dalam perilaku konsumen, terutama dalam hal pencarian informasi dan pembuatan keputusan pembelian (Brown, Broderick, \& Lee, 2007), dan lebih berpotensi dalam membujuk pelanggan untuk membeli suatu merek dibandingkan saluran pemasaran lainnya (Goellner \& Katharina 2012). Brand image merupakan anggapan maupun simbolisme pribadi yang diasosiasikan konsumen terhadap suatu merek, terdiri dari semua informasi deskriptif dan evaluatif yang berkaitan dengan sebuah merek (Iversen \& Hem, 2008). Ketika konsumen memiliki brand image yang baik, maka pesan merek tersebut menjadi lebih berpengaruh dibandingkan dengan pesan yang disampaikan oleh merek pesaing (Hsieh \& Li, 2008). Oleh karena itu, brand image merupakan faktor penting yang menentukan perilaku konsumen (Burmann, Schaefer, \& Maloney, 2008). 


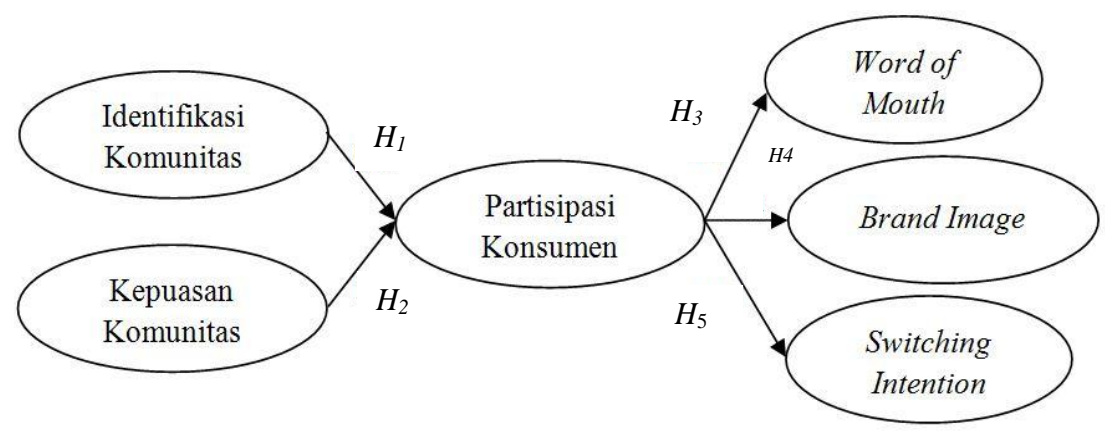

Gambar 1. Model Konseptual Penelitian

\section{Komunitas Merek}

Penelitian Muniz Jr. and O'Guinn (2001) menemukan bahwa komunitas merek dapat terjadi secara langsung (bertatap muka) maupun melalui lingkungan yang termediasi komputer. Komunitas merek merupakan kumpulan individu yang disituasikan dalam konteks pengonsumsian suatu merek. Berbeda kontras dengan bentuk kelompok lainnya, komunitas merek bukan merupakan segmen dengan gaya hidup yang homogen maupun rangkaian pengonsumsian beberapa merek. Komunitas merek merupakan kumpulan jaringan sosial yang bersifat komersil yang berpusat pada suatu merek. Merek tersebut mengikat kesatuan jaringan sosial.

Komunitas merek berguna bagi konsumen terlihat dalam tiga hal pokok berikut: 1) Keberadaan komunitas merek yang seperti agensi konsumen membuat suara dan aspirasi konsumen lebih kuat didengarkan dibandingkan dengan situasi lainnya, 2) Komunitas merek merupakan sumber informasi yang penting bagi konsumen, karena di dalam komunitas merek konsumen dapat dengan mudah menemukan kawan dengan keadaan yang sama, 3) Seperti halnya komunitas lainnya, komunitas merek juga memberikan keuntungan-keuntungan lain bagi anggotanya (Muniz Jr. \& O'Guinn, 2001).

Penelitian mengenai komunitas merek sebelumnya sering menggunakan teori psikologis seperti Social Identity Theory (SIT) dan Psychological Sense of Community (PSOC). Hal tersebut digunakan sebagai landasan dalam menganalisis hubungan antar individu /antar anggota dalam suatu komunitas.

\section{Social Identity Theory}

Social identity adalah bagian dari individual selfconcept yang dikemudikan oleh pengetahuan mengenai keanggotaannya terhadap suatu kelompok sosial bersama dengan nilai dan emosi yang signifikan terikat pada keanggotaan tersebut (Heere et al., 2011). Teori ini menyatakan bahwa individu tidak hanya memiliki identitas personal tetapi juga identitas sosial yang meliputi klasifikasi kelompok yang menonjol. Identitas personal terdiri dari karakteristik spesifik seperti bakat dan minat. Identitas sosial adalah persepsi bahwa dirinya termasuk dalam suatu kelompok (Bhattacharya, Rao, \& Glynn 1995). Konsumen yang mengidentifikasi dirinya dengan merek dan komunitas merek tertentu, kemudian mengklasifikasi dirinya dan konsumen lainnya sebagai anggota kelompok tertentu atau bukan anggota kelompok tertentu (Hickman \& Ward, 2007).

\section{Psychological Sense of Community}

Sebelum meneliti komunitas merek secara lebih lanjut, diperlukan pemahaman terhadap konsep komunitas geografis dan komunitas relasional. Nilai berkomunitas yang digambarkan dalam komunitas yang terbentuk berpusat pada suatu merek tertentu cenderung merupakan konsep komunitas relasional. Tidak peduli konsumen di dalamnya terikat dalam batas geografis yang sama maupun tidak. Carlson et al. (2008) menyatakan tidak diperlukan adanya kontak langsung antar anggota komunitas untuk membangun nilai berkomunitas (sense of community). Sarason (1977) menerangkan sense of community sebagai persepsi kesamaan dengan orang lain, pengakuan atas ketergantungan dengan orang lain, kesediaan untuk menjaga ketergantungan ini dengan memberikan atau melakukan sesuatu untuk mereka, dan perasaan bahwa seseorang merupakan bagian dari struktur mandiri dan stabil yang lebih besar (p. 157).

Identifikasi komunitas didefinisikan sebagai persepsi atau identifikasi bahwa dirinya merupakan bagian dari suatu komunitas. Carlson et al. (2008) berpendapat bahwa identifikasi terhadap komunitas penting untuk mengembangkan PSOC. Semakin kuat identifikasi komunitas merek, semakin sering individu bertindak atas identifikasi tersebut. Tindakan ini dapat menguntungkan perusahaan melalui loyalitas, kesediaan membayar harga lebih tinggi, dan mengaktifkan sense of community di antara anggota komunitas 
merek (Heere et al. 2011). Shih, Hu, and Farn (2010) menyatakan bahwa identifikasi komunitas merupakan antecedent yang penting bagi partisipasi konsumen. Woisetschlager et al. (2008) dan Alagoz, Ekici, and Islek (2011) menghasilkan hubungan positif di antara identifikasi komunitas dan partisipasi konsumen. Mengacu pada berbagai penelitian sebelumnya, hipotesis pertama penelitian ini adalah: $H_{l}$ : Identifikasi komunitas memiliki pengaruh positif terhadap partisipasi konsumen.

Cengiz (2010) menyimpulkan bahwa kepuasan konsumen adalah tingkat keefektifan pelayanan yang diberikan oleh individu, perusahaan, maupun organisasi dalam menjawab kebutuhan konsumen, dalam konteks konsumen secara sadar menggunakan produk atau jasa tersebut. Casalo, Flavian, and Guinaliu (2007) menunjukkan dalam komunitas merek virtual, kepuasan komunitas memiliki pengaruh tidak langsung terhadap partisipasi dalam komunitas tersebut. Hasil yang serupa juga ditunjukkan dalam penelitian Woisetschlager et al. (2008) dan Alagoz et al. (2011) yang menemukan bahwa kepuasan komunitas berpengaruh positif terhadap partisipasi konsumen. Mengacu pada berbagai penelitian sebelumnya, hipotesis kedua penelitian ini adalah: $H_{2}$ : Kepuasan komunitas memiliki pengaruh positif terhadap partisipasi konsumen.

Basalamah (2010) menyimpulkan bahwa Word of Mouth (WOM) adalah komunikasi berupa pembicaraan maupun testimoni yang dilakukan orang dalam membicarakan suatu produk atau jasa. Konsumen yang merasakan kepuasan atas merek tertentu cenderung memberitahukan kelebihan-kelebihan merek tersebut dan kemudian merekomendasikannya kepada orang lain. Rekomendasi dari orang yang pernah/sedang menggunakan merek merupakan alat promosi yang sangat efektif dalam mempengaruhi calon konsumen (Silverman, 2001). Menurut Basalamah (2010) WOM lebih dipercaya oleh calon konsumen daripada sales person karena kekuatan WOM terletak pada kemampuannya dalam memberikan rekomendasi (referral). Algesheimer, Dholakia, and Herrmann (2005) menunjukkan bahwa hubungan dengan komunitas yang lebih kuat mengarah kepada keinginan untuk merekomendasikan komunitas yang lebih kuat. Penelitian Woisetschlager et al. (2008) dan Alagoz et al. (2011) menghasilkan bahwa partisipasi konsumen memiliki pengaruh positif dan signifikan terhadap Word of Mouth. Mengacu pada berbagai penelitian sebelumnya, hipotesis ketiga penelitian ini adalah: $H_{3}$ : Partisipasi konsumen memiliki pengaruh positif terhadap word of mouth.
Brand image yang sukses memungkinkan konsumen untuk mengidentifikasi kebutuhan yang dapat dipenuhi oleh merek tersebut, membedakan merek tersebut dengan pesaing lainnya, dan meningkatkan kecenderungan konsumen untuk melakukan pembelian terhadap merek tersebut (Hsieh, Pan, \& Setiono, 2004). Dalam studi komunitas merek, sering diperdebatkan bahwa pemberdayaan konsumen dan konten yang disediakan untuk konsumen dapat menjadi sangat relevan dalam meningkatkan brand image (Muniz Jr. \& Schau 2007; Woisetschlager et al., 2008; Alagoz et al., 2011) dalam penelitiannya menghasilkan bahwa partisipasi konsumen berpengaruh positif terhadap brand image. Mengacu pada berbagai penelitian sebelumnya, hipotesis keempat penelitian ini adalah: $H_{4}$ : Partisipasi konsumen memiliki pengaruh positif terhadap brand image.

Menurut Thapa (2012) perilaku berpindah pelanggan (costumer's switching behavior) adalah proses yang ditunjukkan oleh pelanggan, yang mana mereka berperilaku berbeda terhadap merek tertentu dan kemudian mengalami perubahan preferensi terhadap produk atau layanan lain yang sudah ada. Kuruuzum and Koksal (2010) menyatakan semakin positif pengalaman konsumen, semakin konsumen cenderung menggunakan kembali jasa atau tetap mengonsumsi produk tersebut. Zengyan, Yinping, and Lim (2009) dalam penelitiannya mengimplikasikan bahwa komunitas merek merupakan salah satu prediktor keinginan berpindah konsumen. Sejalan dengan hal ini, Algesheimer et al. (2005) menunjukkan bahwa semakin kuat ikatan individu dengan komunitasnya mengarah pada keberlangsungan pemakaian merek. Mengacu pada berbagai penelitian sebelumnya, hipotesis terakhir penelitian ini adalah: $\mathrm{H}_{5}$ : Partisipasi konsumen memiliki pengaruh negatif terhadap switching intention.

Penelitian ini dilakukan dengan tujuan untuk mengkonseptualisasi faktor yang berkontribusi dalam kesuksesan partisipasi konsumen dalam komunitas merek dan menyelidiki dampak partisipasi konsumen terhadap word of mouth, brand image, dan switching intention.

\section{Metode Penelitian}

Penelitian dilakukan melalui media internet (secara online), melingkupi seluruh anggota komunitas merek virtual Android. Komunitas merek virtual Android yang diteliti adalah forum online (kaskus, Android-Indonesia, id-android) dan komunitas merek virtual Android yang terbentuk dalam jejaring sosial Facebook. Penelitian dilakukan secara online sehingga dapat mencakup seluruh penjuru Indonesia. 
Populasi penelitian adalah konsumen yang tergabung dalam komunitas merek virtual, sehingga jumlah anggota populasi yang pasti tidak dapat ditentukan. Sampel yang mewakili populasi ditentukan dengan kriteria 5-10 x jumlah parameter $(5-10 \times 26$ = 130-260) (Ferdinand, 2000, p. 44) dan sampel ideal untuk penelitian Maximum Likelihood Estimation (MLE) adalah 100-200 (Latan, 2012, p. 44) sehingga rentang sampel penelitian ini adalah 130-200 sampel. Penelitian ini mengambil jumlah sampel yang aksesibel sebesar 160 sampel. Sampel tersebut diambil dengan metode non-probability sampling, yaitu purposive sampling, yang mana terdapat pertimbanganpertimbangan tertentu dalam pengambilan sampel, yaitu: (1) Responden merupakan pengguna gadget dengan operating system Android, (2) Responden merupakan anggota yang berpartisipasi aktif dalam komunitas merek virtual Android, dan (3) Pendidikan terakhir responden minimal SMP.
Data primer penelitian diperoleh secara langsung dari responden melalui kuesioner online yang dibuat dengan aplikasi Google docs. Caranya adalah disebarkan dengan membuat thread pada komunitas merek virtual Android yang berbentuk forum, membuat post pada wall komunitas merek virtual Android yang terbentuk dalam Facebook, dan mengirim via e-mail kepada responden yang dapat ditemui secara langsung. Hal ini dicegah dengan meminta responden untuk mencantumkan satu komunitas merek virtual Android dimana mereka paling aktif menjadi anggota, sehingga responden hanya perlu mengisi satu kuesioner dengan memberi jawaban yang relevan dengan komunitas merek virtual Android responden cantumkan tersebut.

Berdasarkan uraian tersebut responden penelitian ini terdiri dari $78,75 \%$ (126 orang) laki-laki dan sisanya (34 orang) perempuan. 76,25\% responden berusia dalam rentang 18-30 tahun. Pendidikan terakhir 53,75\% merupakan lulusan SMA, 50\% ber-

Tabel 1

Indikator, Uji Validitas, dan Uji Reliabilitas Konstruk

\begin{tabular}{|c|c|c|}
\hline Indikator & $\begin{array}{l}\text { Loading } \\
\text { Factors }\end{array}$ & $\begin{array}{c}\text { Reliabilitas } \\
\text { Konstruk }\end{array}$ \\
\hline \multicolumn{3}{|l|}{ Identifikasi Komunitas } \\
\hline$\left(X_{l} a\right)$ konsumen melihat dirinya termasuk komunitas & 0,705 & \multirow{7}{*}{0,88} \\
\hline$\left(X_{l} b\right)$ komunitas menjadi bagian dari keseharian konsumen & 0,690 & \\
\hline$\left(X_{l} c\right)$ konsumen melihat dirinya sebagai anggota komunitas yang tipikal dan representatif & 0,684 & \\
\hline$\left(X_{l} d\right)$ konsumen merasa komunitas menegaskan jati dirinya dalam berbagai aspek & 0,679 & \\
\hline$\left(X_{l} e\right)$ konsumen dapat mengidentifikasi dengan komunitas & 0,696 & \\
\hline$\left(X_{I} f\right)$ konsumen memiliki perasaan yang kuat terhadap komunitas & 0,749 & \\
\hline$\left(X_{I} g\right)$ konsumen merasa tepat berada dalam komunitas & 0,727 & \\
\hline \multicolumn{3}{|l|}{ Kepuasan Komunitas } \\
\hline$\left(X_{2} a\right)$ kinerja komunitas secara umum menjawab ekspektasi konsumen & 0,803 & \multirow{3}{*}{0,87} \\
\hline$\left(X_{2} b\right)$ isi/hal-hal di dalam komunitas sangat cocok dengan minat konsumen & 0,862 & \\
\hline$\left(X_{2} c\right)$ komunitas memenuhi kebutuhan konsumen & 0,821 & \\
\hline \multicolumn{3}{|l|}{ Partisipasi Konsumen } \\
\hline$\left(Y_{l} a\right)$ anggota komunitas saling membantu satu sama lain & 0,798 & \multirow{5}{*}{0,90} \\
\hline$\left(Y_{l} b\right)$ konsumen dapat menemukan orang yang suportif dalam komunitas ketika ia memerlukan saran & 0,777 & \\
\hline$\left(Y_{l} c\right)$ konsumen menambah teman baru sebagai hasil dari keanggotaannya & 0,787 & \\
\hline$\left(Y_{l} d\right)$ pertemanan dalam komunitas penting bagi konsumen & 0,781 & \\
\hline$\left(Y_{l} e\right)$ komunitas mendukung kontak sosialdan pertemanan yang ditawarkan sebagai interaksi & 0,857 & \\
\hline \multicolumn{3}{|l|}{ WOM } \\
\hline$\left(Y_{2} a\right)$ konsumen memberitahu orang lain mengenai Android & 0,681 & \multirow{3}{*}{0,89} \\
\hline$\left(Y_{2} b\right)$ konsumen merekomendasikan Android kepada orang lain & 0,797 & \\
\hline$\left(Y_{2} c\right)$ konsumen berkomentar/menuliskan hal positif mengenai Android & 0,658 & \\
\hline \multicolumn{3}{|l|}{ Brand Image } \\
\hline$\left(Y_{3} a\right)$ Android terpercaya & 0,721 & \multirow{5}{*}{0,93} \\
\hline$\left(Y_{3} b\right)$ Android dapat diandalkan & 0,693 & \\
\hline$\left(Y_{3} c\right)$ Android mudah untuk disukai & 0,823 & \\
\hline$\left(Y_{3} d\right)$ Android adalah merek yang sangat baik & 0,799 & \\
\hline$\left(Y_{3} e\right)$ Android merupakan merek yang atraktif/menarik & 0,885 & \\
\hline \multicolumn{3}{|l|}{ Switching Intention } \\
\hline$\left(Y_{4} a\right)$ konsumen bermaksud untuk mengganti merek & 0,681 & \multirow{3}{*}{0,76} \\
\hline$\left(Y_{4} b\right)$ konsumen memilih merek lain untuk penggunaan berikutnya & 0,797 & \\
\hline$\left(Y_{4} c\right)$ konsumen tidak akan menggunakan Android lagi & 0,658 & \\
\hline
\end{tabular}

Sumber: Woisetschlager et al. (2008); Hur, Ahn, and Kim (2011); Shin and Won (2008). 
profesi sebagai pelajar/mahasiswa, dan $74,375 \%$ merupakan anggota aktif dari komunitas merek virtual Android yang terbentuk dalam Facebook.

Ghozali (2004) menyatakan bahwa indikator dikatakan memenuhi uji validitas apabila nilai loading factor $>0,50$ (p. 21). Reliabilitas sebuah konstruk yang dapat diterima adalah $\geq 0,70$ (Ferdinand, 2002, p. 192). Tabel 1 menunjukkan tidak ada nilai loading factor yang bernilai dibawah atau sama dengan 0,50 dan reliabilitas semua konstruk lebih besar dari 0,70, maka data penelitian memenuhi syarat uji validitas dan uji reliabilitas. Jadi data dapat disimpulkan layak digunakan untuk analisis berikutnya.

\section{Hasil dan Pembahasan}

Pengujian hipotesis dilakukan dengan menggunakan teknik analisis SEM (Structural Equation Modeling) untuk melihat hubungan antar konstruk yang kompleks. Ini dikarenakan SEM dapat melakukan pengujian terhadap model pengukuran dan model struktural secara bersamaan. Pengujian terhadap model pengukuran telah dilalui dengan melakukan uji validitas dan uji reliabilitas terhadap masing-masing indikator konstruk, sehingga berikutnya adalah pengujian terhadap model struktural, yang menunjukkan kekuatan estimasi antar variabel (Latan, 2012, p. 2). Awalnya kriteria goodness of fit dari model penelitian tidak terpenuhi dengan baik, sehingga dilakukan modifikasi terhadap model penelitian dengan mengkorelasi hubungan berdasarkan pada indeks modifikasi (Ferdinand, 2002, p. 65). Modifikasi model dilakukan dengan mengkorelasi hubungan indikator dengan indeks modifikasi $\geq 4,0$ (Ferdinand, 2002, p. 65). Nilai tersebut memberikan indikasi bahwa bila koefisien itu diestimasi, maka akan terjadi pengecilan nilai chi-square yang signifikan. Berikut adalah tabel yang menunjukkan nilai indeks modifikasi. Pengkorelasian dengan bantuan indeks modifikasi dilakukan mulai dari hubungan konstruk dengan nilai indeks modifikasi tinggi hingga model memenuhi syarat pengujian.

Lalu dilakukan pengkorelasian terhadap konstrukkonstruk dengan nilai indeks modifikasi 20,023 hingga 8,369. Pengkorelasian delapan hubungan tersebut memberi dampak pengecilan chi-square sebesar 99,46 sehingga model struktural penelitian kini telah memenuhi nilai goodness of fit dengan baik yang ditunjukkan pada Gambar 2 dan Tabel 3.

Tabel 2

Modification Index

\begin{tabular}{|c|c|c|c|}
\hline & & M.I. & $\begin{array}{c}\text { Par } \\
\text { Change }\end{array}$ \\
\hline $\mathrm{e} 2 \leftarrow$ & $\leftrightarrow$ e1 & 20,023 & 0,243 \\
\hline $\mathrm{z} 3 \leftarrow$ & $\leftrightarrow \mathrm{z} 2$ & 19,773 & 0,173 \\
\hline e6 $\leftarrow$ & $\leftrightarrow \mathrm{e} 7$ & 12,056 & 0,136 \\
\hline e18 & $\leftrightarrow \mathrm{z} 3$ & 11,28 & 0,166 \\
\hline $\mathrm{e} 4 \leftarrow$ & $\leftrightarrow \mathrm{e} 2$ & 10,634 & 0,21 \\
\hline e13 & $\leftrightarrow \mathrm{e} 14$ & 9,053 & 0,122 \\
\hline e19 $\leftarrow$ & $\leftrightarrow \mathrm{z} 2$ & 9,003 & 0,134 \\
\hline e15 & $\leftrightarrow \mathrm{z} 3$ & 8,369 & 0,084 \\
\hline e7 $\leftarrow$ & $\leftrightarrow \mathrm{z} 3$ & 7,246 & $-0,114$ \\
\hline $\mathrm{e} 22 \leftarrow$ & $\leftrightarrow \mathrm{e} 25$ & 7,024 & $-0,146$ \\
\hline $\mathrm{e} 8 \leftarrow$ & $\leftrightarrow \mathrm{z} 3$ & 6,778 & $-0,098$ \\
\hline $\mathrm{e} 8 \leftarrow$ & $\leftrightarrow \mathrm{e} 12$ & 6,644 & 0,093 \\
\hline e19 & $\leftrightarrow \mathrm{e} 18$ & 6,486 & 0,144 \\
\hline e1 $\leftarrow$ & $\leftrightarrow$ e 26 & 5,941 & 0,16 \\
\hline $\mathrm{z} 3 \leftarrow$ & $\leftrightarrow$ Community_Identification & 5,772 & $-0,106$ \\
\hline e $4 \leftarrow$ & $\leftrightarrow \mathrm{e} 11$ & 5,623 & $-0,115$ \\
\hline $\mathrm{e} 12 \leftarrow$ & $\leftrightarrow \mathrm{z} 1$ & 5,575 & $-0,054$ \\
\hline e3 $\leftarrow$ & $\leftrightarrow$ Community_Satisfaction & 5,45 & $-0,098$ \\
\hline $\mathrm{e} 2 \leftarrow$ & $\leftrightarrow$ e6 & 5,449 & $-0,111$ \\
\hline e1 & $\leftrightarrow$ e17 & 5,44 & $-0,122$ \\
\hline $\mathrm{z} 4 \leftarrow$ & $\leftrightarrow \mathrm{z} 1$ & 5,015 & $-0,072$ \\
\hline $\mathrm{e} 2 \leftarrow$ & $\leftrightarrow$ e7 & 4,799 & $-0,108$ \\
\hline $\mathrm{e} 4 \leftarrow$ & $\leftrightarrow \mathrm{e} 7$ & 4,686 & $-0,117$ \\
\hline $\mathrm{e} 3 \leftarrow$ & $\leftrightarrow$ e8 & 4,673 & $-0,099$ \\
\hline e19 & $\leftrightarrow \mathrm{e} 10$ & 4,619 & 0,083 \\
\hline e15 & $\leftrightarrow \mathrm{e} 24$ & 4,617 & $-0,087$ \\
\hline $\mathrm{e} 4 \leftarrow$ & $\leftrightarrow$ e6 & 4,586 & $-0,111$ \\
\hline e9 $\leftarrow$ & $\leftrightarrow \mathrm{e} 24$ & 4,548 & 0,095 \\
\hline e17 & $\leftrightarrow \mathrm{z} 3$ & 4,503 & 0,102 \\
\hline $\mathrm{e} 2 \leftarrow$ & $\leftrightarrow$ e 20 & 4,287 & $-0,119$ \\
\hline e19 $\leftarrow$ & $\leftrightarrow$ e 21 & 4,279 & $-0,109$ \\
\hline e16 & $\leftrightarrow \mathrm{e} 25$ & 4,17 & 0,137 \\
\hline e19 $\leftarrow$ & $\leftrightarrow$ e16 & 4,129 & 0,119 \\
\hline e5 & $\leftrightarrow \mathrm{z} 2$ & 4,116 & 0,087 \\
\hline e11 & $\leftrightarrow$ e 22 & 4,099 & $-0,075$ \\
\hline $\mathrm{e} 12 \leftarrow$ & $\leftrightarrow \mathrm{z} 3$ & 4,06 & $-0,082$ \\
\hline $\mathrm{e} 21 \leftarrow$ & $\leftrightarrow \mathrm{e} 13$ & 4,041 & $-0,098$ \\
\hline
\end{tabular}




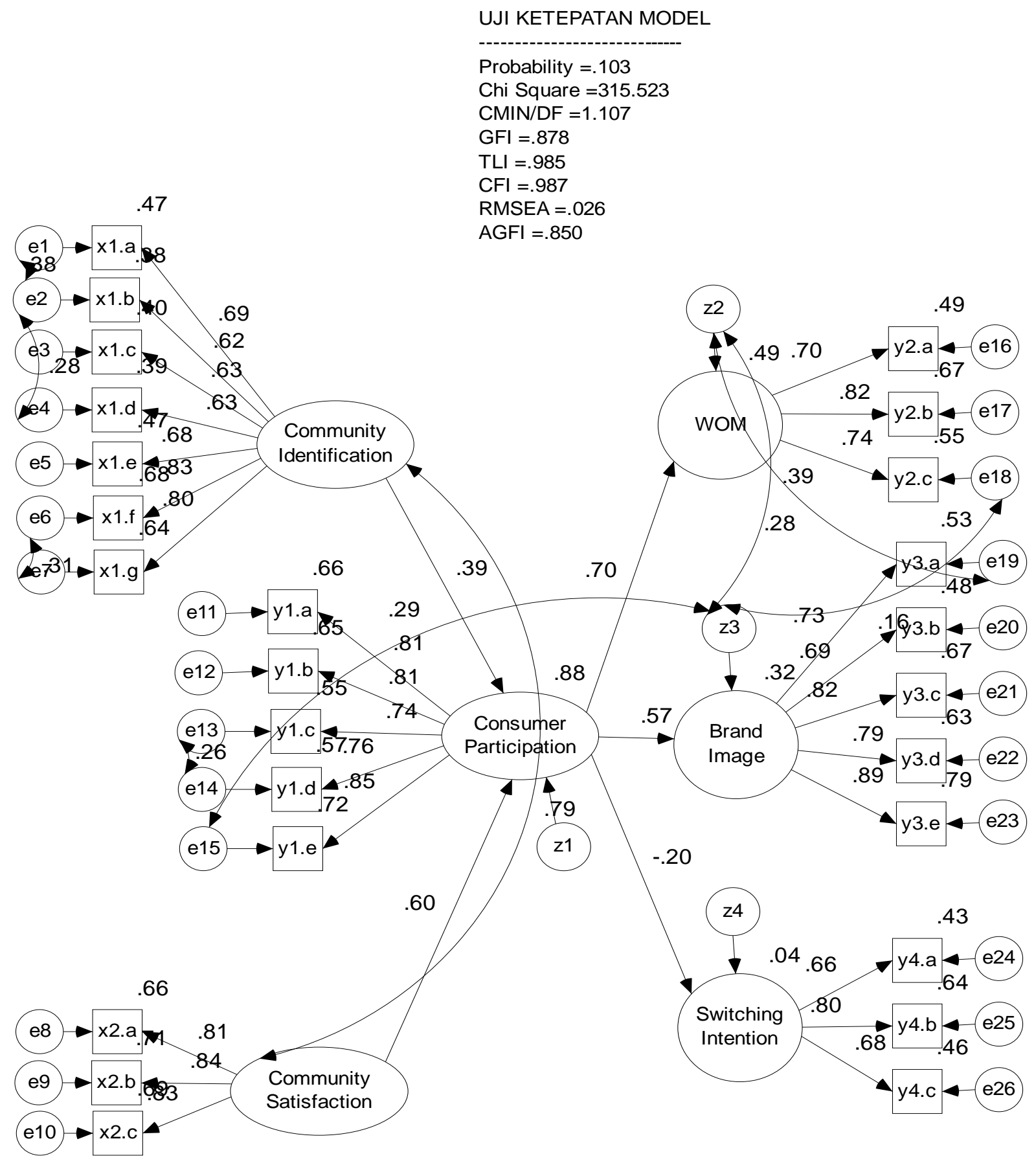

\section{Gambar 2. Model Struktural Setelah Modifikasi}

Tabel 3 menunjukkan nilai goodness of fit model penelitian. Nilai chi-square dan probability yang pada awalnya tidak diterima setelah dilakukan modifikasi menghasilkan nilai yang dapat diterima dengan baik. Data penelitian juga memenuhi asumsiasumsi SEM lainnya, seperti: (1) Evaluasi normalitas, nilai critical ratio data masih dalam rentang $\pm 2,58$ (2) Evaluasi outliers, terdapat sembilan data yang tidak memenuhi evaluasi outlier. Data yang tidak memenuhi evaluasi outlier dapat dibuang untuk memper- baiki penilaian terhadap ketepatan pengujian dengan SEM. Sembilan data yang tidak memenuhi evaluasi outlier dalam penelitian ini tetap digunakan karena membuang data-data tersebut sebaliknya berdampak negatif, (3) Evaluasi multicollinearity dan singularity. Nilai determinant of sample covariance matrix yang dihasilkan oleh data penelitian ini sebesar 0,0000049, yaitu >0 sehingga tidak ada multicollinearity maupun singularity pada data penelitian ini. 
Tabel 3

Kriteria Goodness of Fit setelah Model Dimodifikasi

\begin{tabular}{clccc}
\hline No. & \multicolumn{1}{c}{ Kriteria } & Nilai Kritis & Nilai Model & Kesimpulan \\
\hline 1. & Chi-square & $\leq 352,2375$ & 315,523 & Baik \\
2. & Probability & $\geq 0,05$ & 0,103 & Baik \\
3. & CMIN/DF & $\leq 2,00$ & 1,107 & Baik \\
4. & GFI & $\geq 0,90$ & 0,878 & Marginal \\
5. & TLI & $\geq 0,95$ & 0,985 & Baik \\
6. & CFI & $\geq 0,95$ & 0,987 & Baik \\
7. & RMSEA & $\leq 0,80$ & 0,026 & Baik \\
8. & AGFI & $\geq 0,90$ & 0,810 & Marginal \\
\hline
\end{tabular}

Tabel 4

Regression Weight

\begin{tabular}{llrrrrr}
\hline & & Estimate & S.E. & C.R. & $P$ & Label \\
\hline Consumer_Participation & $\leftarrow$ Community_Identification & 0,306 & 0,077 & 3,982 & $* * *$ & par_14 \\
Consumer_Participation & $\leftarrow$ Community_Satisfaction & 0,581 & 0,099 & 5,851 & $* * *$ & par_15 \\
WOM & $\leftarrow$ Consumer_Participation & 0,724 & 0,106 & 6,827 & $* * *$ & par_22 \\
Brand_Image & $\leftarrow$ Consumer_Participation & 0,629 & 0,093 & 6,749 & $* * *$ & par_23 \\
Switching_Intention & $\leftarrow$ Consumer_Participation & $-0,227$ & 0,108 & $-2,099$ & 0,036 & par_24 \\
\hline
\end{tabular}

Tabel 5

Standardized Total Effects

\begin{tabular}{lcccccc}
\hline & $\begin{array}{c}\text { Community_ } \\
\text { Satisfaction }\end{array}$ & $\begin{array}{c}\text { Community_ } \\
\text { Identification }\end{array}$ & $\begin{array}{c}\text { Consumer_ } \\
\text { Participation }\end{array}$ & $\begin{array}{c}\text { Switching_ } \\
\text { Intention }\end{array}$ & $\begin{array}{c}\text { Brand_ } \\
\text { Image }\end{array}$ & WOM \\
\hline Consumer_Participation & 0,601 & 0,391 & 0,000 & 0,000 & 0,000 & 0,000 \\
Switching_Intention & $-0,119$ & $-0,078$ & $-0,199$ & 0,000 & 0,000 & 0,000 \\
WOM & 0,419 & 0,273 & 0,698 & 0,000 & 0,000 & 0,000 \\
Brand_Image & 0,340 & 0,221 & 0,566 & 0,000 & 0,000 & 0,000 \\
\hline
\end{tabular}

\section{Pengujian Hipotesis}

Berikutnya dilakukan pengujian terhadap hubungan yang dibentuk dalam hipotesis-hipotesis penelitian, dengan melihat signifikan tidaknya hubungan tersebut melalui nilai critical ratio (CR) pada tabel berikut. Hubungan dikatakan signifikan apabila nilai CR tidak sama dengan 0, sehingga hubungan kausalitas yang signifikan dari variabel-variabel yang hubungannya digambarkan pada model penelitian ini dapat diterima.

Tabel 5 menunjukkan hubungan langsung dan tidak langsung dari masing-masing variabel. Dapat dilihat pada tabel di atas bahwa dari dua variabel yang memiliki hubungan langsung terhadap partisipasi konsumen. Hubungan yang lebih kuat berasal dari kepuasan komunitas (sebesar 0,601), sedangkan partisipasi konsumen memiliki pengaruh langsung terhadap variabel brand image (sebesar 0,566), WOM (sebesar 0,698), dan switching intention (sebesar-0,199, yang menandakan pengaruh negatif).

Tabel 5 menunjukkan adanya hubungan tidak langsung antara variabel-variabel penelitian. Dapat dilihat pada tabel tersebut bahwa dari dua variabel yang memiliki hubungan langsung terhadap partisi- pasi konsumen. Hubungan yang lebih kuat berasal dari kepuasan komunitas (sebesar 0,601), sedangkan partisipasi konsumen memiliki pengaruh langsung terhadap variabel brand image (sebesar 0,566), WOM (sebesar 0,698), dan switching intention (sebesar -0,199, yang menandakan pengaruh negatif). Pengaruh tidak langsung yang diberikan oleh kepuasan komunitas terhadap ketiga variabel konsekuensi lebih besar dari pengaruh tidak langsung yang diberikan oleh identifikasi komunitas. Hal ini sejalan dengan hasil yang menunjukkan pengaruh langsung yang diberikan oleh kepuasan komunitas terhadap partisipasi konsumen lebih besar dari pengaruh yang diberikan oleh identifikasi komunitas.

Pembahasan di atas menunjukkan bahwa kelima hipotesis penelitian diterima. Hipotesis $H_{5}$ mengembangkan model konseptual yang dikembangkan oleh Woisetschlager et al. (2008) dan Alagoz et al. (2011).

\section{Pembahasan}

Berdasarkan uraian hasil penelitian di atas, dapat diimplikasikan bahwa: 1) Teori identitas sosial menyatakan bahwa individu mempersepsikan dirinya 
termasuk dalam suatu kelompok, dengan kata lain mereka mengidentifikasikan diri ke dalam suatu komunitas. Konsumen yang mengidentifikasikan dirinya ke dalam komunitas merek virtual menguntungkan perusahaan karena konsumen akan menjadi lebih loyal, bersedia membayar harga yang lebih tinggi, dan cenderung menarik konsumen lain kedalam komunitas sebagai bentuk dari rasa berkomunitas. Kecenderungan ini meningkatkan partisipasi konsumen dalam komunitas merek tersebut. Pemasar dapat meningkatkan identifikasi komunitas dengan meningkatkan kemudahan infrastruktur dalam komunitas, menjaga suasana interaksi antar anggota agar tetap nyaman, memberikan jawaban atas kesulitan yang dialami sebaik mungkin, dan menjaga kualitas informasi yang beredar di dalam komunitas agar tidak keluar dari identitas komunitas dan tetap reliable; 2) Kepuasan merupakan penyebab utama loyalitas. Konsumen yang loyal cenderung terlibat lebih banyak di dalam kegiatan komunitas merek. Konsumen yang merasa kebutuhannya dipuaskan oleh kinerja komunitas merek dapat menumbuhkan sense of community karena mereka merasa tidak salah memilih sumber informasi, cenderung lebih mudah untuk menuangkan aspirasinya mengenai merek tertentu, dan cenderung mudah untuk mempercayakan kesulitannya pada komunitas merek tersebut. Hal ini bermanfaat bagi komunitas merek karena konsumen yang merasakan sense of community akan mengakui ketergantungan mereka dengan komunitas merek tersebut beserta isinya, bersedia menjaga ketergantungan tersebut, dan bersedia melakukan sesuatu untuk anggota komunitas tersebut. Hal ini dapat menghidupkan interaksi, dan meningkatkan partisipasi konsumen dalam komunitas merek tersebut; 3) Dalam membangun dan kemudian menjaga partisipasi konsumen dalam suatu komunitas merek, manajemen dan pemasar sebaiknya lebih mengutamakan kepuasan anggota komunitas terhadap kinerja komunitas. Kepuasan komunitas dapat mengikat konsumen terhadap suatu komunitas merek lebih kuat daripada identifikasi komunitas karena kepuasan lebih mudah dirasakan secara langsung oleh konsumen. Kepuasan dapat dirangsang dari komunitas merek dengan memberikan pelayanan yang melebihi ekspektasi konsumen, sedangkan identifikasi diri konsumen terhadap komunitas harus menunggu tumbuh dengan sendirinya dari dalam diri konsumen. Tidak ada patokan yang jelas dalam mengukur seorang individu mengidentifikasi diri terhadap komunitas merek tertentu atau tidak. Oleh karena itu, identifikasi komunitas lebih sulit untuk diberdayakan oleh perusahaan. Hal ini menyebabkan pemberdayaan kepuasan konsumen terhadap komunitas merek akan memberikan hasil yang lebih signifikan terhadap keberhasilan komunitas merek itu sendiri. Jika dilihat dari deskripsi variabel partisipasi konsumen, indikator yang paling tinggi mempengaruhi partisipasi konsumen dalam komunitas merek virtual adalah kesediaan anggota untuk saling membantu satu sama lain, dan konsumen mendapatkan teman baru dari komunitas tersebut. Hal yang perlu diperhatikan dalam meningkatkan partisipasi konsumen adalah kemudahan dan hubungan harmonis dalam berinteraksi di dalam komunitas; 4) Untuk menjamin kesuksesan komunitas merek, pihak manajemen dan pemasar sebaiknya merangsang dan kemudian menjaga partisipasi anggotaanggota di dalam komunitas merek. Seperti yang telah dipaparkan dalam landasan teori dan dibuktikan oleh hasil penelitian ini bahwa partisipasi konsumen dapat merangsang munculnya tindakan Word of Mouth positif, menciptakan brand image yang baik, dan mempertahankan pelanggan dengan mencegah timbulnya switching intention; 5) Interaksi dalam komunitas merek memungkinkan anggota untuk saling membagi pengalaman dan pemikiran mengenai Android. Konsumen yang berpartisipasi aktif dalam komunitas memiliki lebih banyak pengetahuan mengenai Android sehingga cenderung lebih mudah melakukan Word of Mouth, baik di dalam maupun di luar komunitas merek tersebut. Konsumen yang berpartisipasi dalam komunitas akibat identifikasi dan kepuasan yang dirasakannya terhadap komunitas dipercaya menyebarkan Word of Mouth positif, karena ikatan yang dirasakannya terhadap komuntias merek tersebut. Word of Mouth positif bermanfaat bagi perusahaan dalam meningkatkan jumlah konsumen baru, yang sesungguhnya diperlukan biaya yang tinggi untuk menarik konsumen baru. Konsumen-konsumen baru tersebut kemudian dipertahankan dengan adanya komunitas merek; 6) Konsumen yang berpartisipasi secara aktif dalam komunitas merek menerima lebih banyak informasi mengenai Android. Ketika terdapat informasi negatif mengenai Android, konsumen dalam komunitas merek dapat dengan segera mendiskusikan informasi tersebut sehingga dapat mencegah terbentuknya brand image negatif dalam benak konsumen. Brand image membekali konsumen ide mengenai kebutuhan apa yang dapat dipenuhi oleh Android. Brand image yang baik dapat memperkuat persepsi pelanggan bahwa ia telah melakukan pilihan yang benar dengan menggunakan merek Android, sehingga konsumen akan cenderung bergantung pada Android untuk pemenuhian kebutuhannya tersebut; 7) Dalam penelitian ini dibuktikan adanya pengaruh langsung dari partisipasi konsumen terhadap keinginan untuk berpindah. Konsumen dalam komunitas merek yang telah mengidentifikasikan diri dan me- 
rasakan kepuasan terhadap komunitas cenderung memiliki persepsi bahwa produk sejenis dari pesaing lebih jelek dari Android, karena keanggotaan dalam komunitas merek tertentu membuat konsumen merasakan keharusan untuk merendahkan merek pesaing (Muniz Jr. \& O’Guinn, 2001).

Hal ini menjauhkan pelanggan dari keinginan untuk mencoba produk milik pesaing (switching intention). Pencegahan switching intention juga akan mencegah pelanggan untuk berpaling ke merek pesaing, sehingga kemungkinan perkembangan pangsa pasar dan keuntungan hanya akan menuju arah yang positif atau hanya akan semakin bertambah. Dilihat dari deskripsi variabel switching intention, indikator yang menyebutkan bahwa konsumen tidak akan lagi menggunakan merek Android memiliki nilai rata-rata paling tinggi. Hal ini fatal bagi pemasar karena akan sangat sulit untuk menarik dan membangkitkan kepercayaan konsumen tersebut kembali. Oleh karena itu, pencegahan timbulnya switching intention sebaiknya dilakukan dengan serius.

\section{Simpulan dan Implikasi}

Identifikasi komunitas memiliki pengaruh positif yang signifikan terhadap partisipasi konsumen dalam komunitas merek virtual. Ketika konsumen merasa menjadi bagian dari suatu komunitas merek virtual konsumen menjadi lebih aktif berpartisipasi dalam aktivitas yang berlangsung di dalam komunitas merek virtual tersebut. Kepuasan komunitas memiliki pengaruh positif yang signifikan terhadap partisipasi konsumen dalam komunitas merek virtual. Konsumen yang merasa puas atas kinerja komunitas merek virtual akan semakin tergantung terhadap komunitas tersebut sehingga tertarik untuk lebih dalam terlibat dalam komunitas merek virtual tersebut. Partisipasi konsumen memiliki pengaruh positif yang signifikan terhadap tindakan Word of Mouth positif. Konsumen yang berpartisipasi aktif dalam komunitas merek virtual menerima lebih banyak informasi positif mengenai produk sehingga dapat lebih banyak melakukan Word of Mouth positif. Partisipasi konsumen memiliki pengaruh positif yang signifikan terhadap brand image. Konsumen yang secara aktif berinteraksi dalam komunitas merek virtual juga dapat menerima informasi maupun pengalaman dari konsumen lain sehingga brand image yang dimiliki lebih kuat, karena konsumen secara tidak langsung memposisikan diri pada situasi konsumen lain yang mengalami. Partisipasi konsumen memiliki pengaruh negatif yang signifikan terhadap switching intention. Konsumen yang berpartisipasi aktif dalam komunitas merek cenderung tidak memiliki keinginan untuk beralih karena ketika keinginan itu mulai muncul, konsumen memiliki tempat untuk mengonfirmasi keinginannya, dan akhirnya mengurungkan niat karena menerima pelurusan dari konsumen lain di komunitas merek virtual tersebut. Penelitian ini menemukan bahwa identifikasi komunitas dan kepuasan komunitas memiliki pengaruh tidak langsung terhadap Word of Mouth positif, brand image, dan switching intention, sehingga terbukti adanya hubungan di antara antecedents (penyebab) dan consequences (konsekuensi) partisipasi konsumen dalam komunitas merek virtual.

Pihak pemasar dan manajemen Android Inc. sebaiknya mulai serius dalam menanggapi keberadaan komunitas merek virtual yang telah berkembang, karena seperti yang dikatakan oleh Saputri (2009) bahwa kini dalam dunia pemasaran segmentasi konsumen ke dalam komunitas dirasa lebih efektif. Ada baiknya menjadikan komunitas merek virtual yang kini berkembang menjadi official tanpa mengurangi kemudahan akses maupun fasilitas yang ditawarkan untuk menjaga niat berpartisipasi konsumen, melainkan meningkatkan kinerja komunitas konsumen untuk meningkatkan kepuasan anggota di dalamnya. Hal ini lebih bijak karena komunitas sudah memiliki fondasi, pemasar dan manajemen hanya perlu pengelolaan dan pengawasan yang memungkinkan Android Inc. mengakses dan mempelajari perkembangannya secara langsung. Bagi peneliti berikutnya, untuk menambahkan asal daerah pada karakteristik responden sehingga dapat dipastikan penelitian mencakup seluruh Indonesia. Penelitian berikutnya juga dapat meneliti variabel lain, seperti: pengalaman dengan merek tersebut, tersedianya pilihan lain sebagai variabel penyebab, atau kesetiaan dan komitmen sebagai akibat dari partisipasi dalam komunitas merek. Menggunakan indikator switching intention yang dapat menggambarkan penyebab switching intention itu sendiri.

Implikasi penelitian tidak dapat menggambarkan komunitas merek virtual secara umum, karena penelitian hanya dilakukan pada komunitas-komunitas merek virtual Android. Terdapat kekhawatiran bahwa responden tidak menjawab kuesioner dengan jujur karena kuesioner disebarkan secara online. Keraguan mengenai penelitian yang mencangkup seluruh wilayah Indonesia karena tidak secara jelas tergambarkan dalam karakteristik responden.

\section{Daftar Referensi}

Alagoz, S. B., Ekici, N., \& Islek, M. S. (2011). Brand communities in the axis of socializing customers: Sample of Volkswagen beetle owners, Turkey. Ege Academic Review, 11(3), 465-477. 
Algesheimer, R., Dholakia, U. M., \& Herrmann, A. (2005). The social influence of brand community: Evidence from european car clubs. Journal of Marketing, 69(3), 19-34.

Basalamah, F. M. (2010). Pengaruh komunitas merek terhadap word of mouth. Jurnal Ilmu Administrasi dan Organisasi, 17(1), 79-89.

Bhattacharya, C. B., Rao, H., \& Glynn, M. A. (1995). Understanding the bond of identification: An investigation of its correlates among art museum members. Journal of Marketing, 59(4), 46-57.

Brown, J., Broderick, A. J., \& Lee, N. (2007). Word of mouth communication within online communities: conceptualizing the online social network. Journal of Interaction Marketing, 21(3), 2-20.

Burmann, C., Schaefer, K., \& Maloney, P. (2008). Industry image: Its impact on the brand image of potential employees. Journal of Brand Management, 15, 157-176.

Carlson, B. D., Suter, T. A., \& Brown, T. J. (2008). Social versus psychological brand community: The role of psychological sense of brand community. Journal of Business Research, 61, 284 291.

Casalo, L., Flavian, C., \& Guinaliu, M. (2007). The impact of participation in virtual brand communities on consumer trust and loyalty. Online Information Review, 31(6), 775-792.

Cengiz, E. (2010). Measuring customers satisfaction: must or not? Journal of Naval Science and Engineering, 6(2), 76-88.

Ferdinand, A. (2000). Structural equation modeling dalam penelitian manajemen: Aplikasi modelmodel rumit dalam penelitian untuk tesis $\mathrm{S}-2$ dan disertasi $S$-3. Semarang: BP Universitas Diponegoro.

--_--- (2002). Structural equation modelling dalam penelitian manajemen: Aplikasi modelmodel rumit dalam penelitian untuk tesis magister \& disertasi doktor. Semarang: BP UNDIP.

Goellner \& Katharina. (2012). Brand community duty: The role of duty in brand communities. Unpublished thesis of Master of Science in Marketing \& Consumer Studies. The University of Guelph, Guelph, Ontario, Canada.

Ghozali, I. (2004). Model persamaan struktural: Konsep dan aplikasi dengan program AMOS Ver. 5.0. Semarang: BP Universitas Diponegoro.

Heere, B., Walker, M., Yoshida, M., Ko, Y. J., Jordan, J. S., \& James, J. D. (2011). Brand community development through assosiated communities grounding community measurement within social identity theory. Journal of Marketing Theory and Practice, 19(4), 407-422.
Hickman, T., \& Ward, J. (2007). The dark side of brand commnunity: Inter-group stereotyping, trach talk, and schandenfreude. Advances in Consumer Research, 34, 314-319.

Hsieh, A. T. \& Li, C. K. (2008). The moderating effect of brand image on public relations perception and customer loyalty. Marketing Intelligence \& Planning, 26(1), 26-42.

Hsieh, M. H., Pan, S. L., \& Setiono, R. (2004). Product, corporate, and country-image dimensions and purchase behavior: A multicountry analysis. Journal of the Academy of Marketing Science, 32(3), 251-270.

Hur, W. M., Ahn, K. H., \& Kim, M. (2011). Building brand loyalty through managing brand community commitment. Management Decision, 49(7), 1194-1213.

Iversen, N. M., \& Hem, L. E. (2008). Provenance associations as core values of place umbrella brands. European Journal of Marketing, 42(5/6), 603-626.

JIBI. (Mei, 2013). Android dominasi 64,2\% penjualan smartphone di pasar global. Retrieved May 12, 2013, from http://www.bisnis-kti.com/index. php/2013/05/android-dominasi-642-penjualansmartphone-di-pasar-global/.

Kotler, P., \& Keller, K. L. (2009). Manajemen pemasaran, Edisi 12, Jilid 1. Jakarta: PT. Indeks.

Kuruuzum, A., \& Koksal, C. D. (2010). The impact of service quality on behavioral intention in hospitality tndustry. International Journal of Business and Management Studies, 2(1), 9-15.

Latan, H. (2012). Structural equation modeling: Konsep dan aplikasi menggunakan program LISREL 8.80. Bandung: Penerbit Alfabeta.

McAlexander, J. H., Kim, S. K., \& Roberts, S. D. (2003). Loyalty: The influences of satisfaction and brand community integration. Journal of Marketing Theory and Practice, 11(4), 1-11.

McAlexander, J. H., Schouten, J. W., \& Koenig, H. F (2002). Building brand community. Journal of Marketing, 66(1), 38-54.

Muniz Jr., A. M., \& O'Guinn, T. C. (2001). Brand community. Journal of Consumer Research, 27(4), 412-432.

Muniz Jr., A. M., \& Schau, H. J. (2007). Vigilante marketing and consumer-created communication. Journal of Advertising, 36(3), 35-50.

Royo-Vela, M., \& Casamassima, P. (2011). The influence of belonging to virtual brand communities on consumers' affective commitment, satisfaction and word-of-mouth advertising. Online Information Review, 35(4), 517-542.

Saputri, A. (2009). Analisis pengaruh iklan media TV terhadap keputusan pembelian konsumen pada 
provider simpati PEDE. Skripsi. Universitas Pembangunan Negeri Veteran, Jakarta.

Sarason, S. B. (1977). The psychological sense of community: Prospects for a community psychology. London, UK: Proquest Info \& Learning.

Shih, P. C., Hu, H. Y., \& Farn, C. K. (2010). Lead user participation in brand community: The case of Microsoft MVPS. International Journal of Electronics Business Management, 8(4), 323331.

Shin, D. H., \& Won, Y. K. (2008). Forcasting customer switching intention in mobile service: An exploratory study of predictive factors in mobile numer portability. Technological Forecasting and Social Change, 75, 854-874.

Silverman, G. (2001). The secrets of word of mouth marketing: How to trigger expontential sales through runaway word of mouth. USA: AmaCom.
Tentangdunia. (2013, 4 April). Penjualan handphone di Indonesia. Retrieved May 18, 2013, from http://www.tentangdunia.com/2756-penjualanhandphone-di-indonesia.html.

Thapa, A. (2012). Consumer switching behavior: A study of shampoo brands. Journal of Research in Commerce \& Management, 1(9), 98-106.

Woisetschlager, D. M., Hartleb, V., \& Blut, M. (2008). How to make brand communities work: Antecedents and consequences of consumer participation. Journal of Relationship Marketing, 73 (3), 237-256.

Zengyan, C., Yinping, Y., \& Lim, J. (2009). Cyber migration: An empirical investigation on factors that affects users' switch intentions in social networking sites. Proceedings of the 42nd Hawaii International Conference on System Sciences. 